\title{
Impact of post-hospital cardiac rehabilitation on the quality of life of patients after surgical treatment for coronary artery disease
}

\author{
Józefa Dąbek¹, Ewelina Pyka , Joanna Piotrkowicz¹, Krystian Stachoń², Grażyna Bonek-Wytrych ${ }^{3}$ \\ ${ }^{1}$ School of Health Science in Katowice, Department of Cardiology, Medical University of Silesia, Katowice, Poland \\ ${ }^{2}$ Department of Anesthesiology and Intensive Care with Cardiac Monitoring, Independent Public Clinical Hospital No. 7 , \\ Upper Silesian Medical Center, Medical University of Silesia, Katowice, Poland \\ ${ }^{3}$ Department for Health Care Supervision, Voivodeship Office, Katowice, Poland
}

Kardiochirurgia i Torakochirurgia Polska 2017; 14 (2): 120-126

\begin{abstract}
Introduction: The quality of life of cardiovascular patients is worse than that of healthy individuals. Pain, dyspnea, and fatigue impair daily activities, which in turn leads to decreased life satisfaction and emotional deterioration. The objective of comprehensive treatment, including early rehabilitation, is to reduce the risk of complications, progression, and recurrence of the disease, as well as to restore, maintain, or improve all aspects of the patient's quality of life to the greatest extent possible.

Aim: To assess the quality of life of patients who underwent surgical treatment for coronary artery disease and completed the second phase of cardiac rehabilitation.

Material and methods: The study enrolled 100 patients undergoing early cardiac rehabilitation in stationary conditions after coronary artery bypass grafting. The group included 21 women and 79 men; their age ranged from 40 to 75 years. The study employed a questionnaire of our own design.

Results: Post-hospital cardiac rehabilitation resulted in quality of life improvements, especially with regard to psychological aspects, reducing the occurrence of anxiety from $44 \%$ to $21 \%$. In addition, the rehabilitation program reduced the occurrence of subjective ailments such as chest pain (from 68\% to 10\%), fatigue (from $40 \%$ to $33 \%$ ), and dyspnea (from $50 \%$ to $12 \%$ ). Conclusions: Despite the achievement of quality of life improvements among patients after surgery coronary artery bypass grafting and early cardiac rehabilitation, the result is not fully satisfactory. Systematic treatment and education should be continued to further improve the health of patients.

Key words: cardiac rehabilitation, quality of life, vascular bypass.
\end{abstract}

\section{Streszczenie}

Wstęp: Jakość życia pacjentów z chorobami układu krążenia jest gorsza w porównaniu z osobami zdrowymi. Ból, duszność, poczucie zmęczenia upośledzają wykonywanie codziennych czynności. Prowadzi to do obniżenia zadowolenia z życia i pogorszenia stanu emocjonalnego tych chorych. Celem kompleksowego leczenia, w tym wczesnej rehabilitacji, jest zmniejszenie ryzyka rozwoju powikłań, progresji i nawrotów choroby oraz jeśli jest to możliwe, przywrócenie, podtrzymanie lub poprawa jakości ich życia we wszystkich jego sferach.

Cel: Ocena jakości życia chorych poddanych operacyjnemu leczeniu choroby wieńcowej po zakończeniu drugiego etapu rehabilitacji kardiologicznej.

Materiał i metody: Do badań zakwalifikowano 100 chorych objętych procesem wczesnej rehabilitacji kardiologicznej w warunkach stacjonarnych po zabiegu pomostowania aortalno-wieńcowego. Wśród nich było 21 kobiet i 79 mężczyzn w wieku od 40 do 75 lat. W badaniach posłużono się autorskim kwestionariuszem ankiety.

Wyniki: Poszpitalna rehabilitacja kardiologiczna wpłynęła na poprawę jakości życia chorych, zwłaszcza w sferze psychicznej, zmniejszając występowanie lęku (z 44\% do 21\%). Ponadto zmniejszyło się odczuwanie subiektywnych dolegliwości, takich jak ból w klatce piersiowej (z 68\% do 10\%), męczliwość (z 40\% do 33\%) i duszność (z 50\% do 12\%).

Wnioski: Wczesna rehabilitacja kardiologiczna przyczyniła się do poprawy jakości życia chorych po operacyjnym leczeniu choroby wieńcowej (by-passach). Pomimo poprawy jakości życia chorych w wyniku leczenia i przeprowadzonej wczesnej rehabilitacji kardiologicznej jej wynik nie jest w pełni zadowalający. Należy kontynuować proces leczniczy i edukację chorych w sposób ciągły i systematyczny w celu dalszej poprawy stanu ich zdrowia.

Słowa kluczowe: rehabilitacja kardiologiczna, jakość życia, pomostowanie naczyniowe.

Address for correspondence: Joanna Piotrkowicz, School of Health Science in Katowice, Department of Cardiology, Medical University of Silesia, 45/47 Ziołowa St, 40-031 Katowice, Poland, phone: +48 505072 509, fax: +48 662 226 446, e-mail: joanna.piotrkowicz@gmail.com Received: 3.04.2017, accepted: 5.06.2017. 


\section{Introduction}

Quality of life (QoL) is a broad term which encompasses: physical condition including motor fitness, mental condition - satisfaction from life, socio-economic status, and somatic experiences [1-3]. According to the World Health Organization (WHO), good quality of life entails the ability to function normally and experience satisfaction from performing daily activities; it includes physical fitness, independence, sufficient energy for self-care, emotional stability, absence of pain or discomfort, as well as adequate sleep and rest [4].

Medically, QoL encompasses the patient's health status, diseases, and aging processes, as well as the influence of these factors on the patient's functioning.

Cardiovascular diseases and their complications are the most frequent cause of death in Poland and around the world, surpassing even neoplasms in this respect [5]. World Health Organization estimates that the number of deaths due to ischemic heart disease will rise from 7.1 million in 2002 to 11.1 million in 2020 [6].

The treatment of coronary artery disease depends on its presentation and symptom intensity. The primary goals of treatment are to improve prognosis, reduce the risk of acute coronary syndromes, and improve the QoL of affected patients. These goals can be realized by eliminating risk factors, changing the patient's lifestyle, providing pharmacological treatment, or, when necessary, performing myocardial revascularization. Invasive treatment includes percutaneous coronary intervention $(\mathrm{PCl})$ and coronary artery bypass grafting (CABG) [6]. The procedures aim to reduce myocardial ischemia and limit its unfavorable clinical symptoms. Indications for revascularization include symptoms persisting despite pharmacological treatment and/or a desire to improve prognosis [7]. The choice of the revascularization method depends on the patient's condition; both the potential benefits and the risks associated with the procedure should be considered. Coronary artery bypass grafting offers the greatest benefits to patients with advanced coronary artery disease and significant anginal complaints. The procedure enables quick improvement of both health status and quality of life, but it should be noted that it is more invasive and strenuous for the patients. An important role in preventing postoperative complications and ensuring quick recovery is played by cardiac rehabilitation, which should be started as soon as possible. The aim of cardiac rehabilitation conducted as part of secondary prevention is to improve the patient's quality of life in all its dimensions [8].

Quality of life measurement is used increasingly often as a criterion for treatment outcome evaluation in cardiology [9].

There are numerous scientific reports indicating that all QoL aspects improve after CABG, regardless of sex; however, the results remains ambiguous as some patients report no QoL improvement or even its deterioration after the treatment, which means that they experience no health status improvement [10]. Despite the surgical treatment, the level of anxiety and depression of some patients remains high after CABG. The factors most often reported as responsible for this state of affairs include: the course of the recovery process, recurrence of cardiovascular events, time from the procedure, and reduced quality of life [11]. Most publications evaluate QoL after at least several months from the treatment. In turn, our study evaluated quality of life during the early postoperative period. We investigated whether the QoL of patients improved despite the short period of time that had passed from the surgery and early cardiac rehabilitation.

\section{Aim}

The aim of the study was to evaluate the quality of life of patients who had undergone surgical treatment for coronary artery disease and completed the $2^{\text {nd }}$ stage of cardiac rehabilitation.

\section{Material and methods}

The study included all consecutive patients who had undergone surgical treatment for coronary artery disease (CABG) and had completed the stage of stationary posthospital rehabilitation conducted at a cardiac spa hospital; all subjects provided their consent to participate in the study. A validated questionnaire of our own design was used; the questionnaire is presented at the end of this paper. It included questions concerning risk factors, lifestyle, physical activity, and subjective ailments. The questionnaire was distributed twice: on the first and the last day of the rehabilitation cycle. The exclusion criteria included lack of consent or poor health status precluding participation. The data were gathered in a database and analyzed.

\section{Statistical analysis}

Statistical analysis was performed using Statistica 8.0 software. Descriptive statistics were used to present general characteristics of the study group. Relations between the parameters were evaluated using a $\chi^{2}$ test.

\section{Results}

The number of questionnaires distributed was 116. After the forms that were filled out incorrectly were eliminated, the final analysis encompassed questionnaires from 100 patients. The study included 21 women and 79 men; their age ranged from 40 to 79 years $(58.42 \pm 12.71)$.

Study group characteristics including demographic data are presented in Table I.

A decided majority of the subjects were men. Patients between 50 and 70 years of age constituted the largest age group.

The CABG treatment was performed as elective procedures in $30 \%$ of patients; the procedures were semi-elective in $26 \%$ of cases and urgent in as many as $44 \%$ of patients.

The study group characteristics concerning concomitant diseases are presented in Figure 1.

The most frequent concomitant condition was arterial hypertension. 
Tab. I. Study group characteristics - demographic data $(n=100)$

\begin{tabular}{llcc}
\multirow{2}{*}{ Variable } & & \multicolumn{2}{c}{ Group size } \\
\cline { 2 - 4 } & Women & $n$ & $\%$ \\
\cline { 2 - 4 } & Men & 21 & 21 \\
\hline Age [years] & Up to 40 & 79 & 79 \\
\cline { 2 - 4 } & $41-50$ & 2 & 2 \\
\cline { 2 - 4 } & $51-60$ & 32 & 52 \\
\cline { 2 - 4 } & $61-70$ & 39 & 39 \\
\cline { 2 - 4 } & More than 70 & 22 & 22 \\
\hline Place of residence & Urban & 60 & 60 \\
\cline { 2 - 4 } & Rural & 40 & 40 \\
\hline Education & Primary & 33 & 19 \\
\cline { 2 - 4 } & Vocational & 33 \\
\cline { 2 - 4 } & Secondary & 32 \\
\cline { 2 - 4 } & Higher & 16 \\
\hline
\end{tabular}

Tab. II. Study group characteristics - preoperative and postoperative physical activity

\begin{tabular}{|c|c|c|c|c|c|}
\hline \multicolumn{2}{|c|}{ Physical activity } & \multicolumn{2}{|c|}{$\begin{array}{l}\text { Before the } \\
\text { procedure }\end{array}$} & \multicolumn{2}{|c|}{$\begin{array}{l}\text { After the } \\
\text { procedure }\end{array}$} \\
\hline & & $n$ & $\%$ & $n$ & $\%$ \\
\hline \multirow[t]{3}{*}{$\begin{array}{l}\text { Free-time } \\
\text { activities }\end{array}$} & $\begin{array}{l}\text { Watching TV, reading } \\
\text { books, napping }\end{array}$ & 58 & 58 & 32 & 32 \\
\hline & $\begin{array}{l}\text { Walking, movement, } \\
\text { recreation }\end{array}$ & 18 & 18 & 68 & 68 \\
\hline & $\begin{array}{l}\text { Household chores, } \\
\text { gardening }\end{array}$ & 24 & 24 & 0 & 0 \\
\hline \multirow{6}{*}{$\begin{array}{l}\text { Timed } \\
\text { devoted } \\
\text { to physical } \\
\text { activity }\end{array}$} & Everyday & 18 & 18 & 49 & 49 \\
\hline & 3-4 times per week & 12 & 12 & 25 & 25 \\
\hline & Once per week & 14 & 14 & 6 & 6 \\
\hline & Twice per month & 5 & 5 & 2 & 2 \\
\hline & Once per month & 9 & 9 & 1 & 1 \\
\hline & Not active & 42 & 42 & 17 & 17 \\
\hline \multirow{4}{*}{$\begin{array}{l}\text { Limitations in } \\
\text { daily activities }\end{array}$} & No limitations & 34 & 34 & 16 & 16 \\
\hline & Slight limitations & 27 & 27 & 42 & 42 \\
\hline & Significant limitations & 14 & 14 & 26 & 26 \\
\hline & $\begin{array}{l}\text { Ailments precluding } \\
\text { any activity }\end{array}$ & 25 & 25 & 16 & 16 \\
\hline \multirow[t]{4}{*}{$\begin{array}{l}\text { Difficult } \\
\text { activities }\end{array}$} & $\begin{array}{l}\text { Dressing, using } \\
\text { the bathroom }\end{array}$ & 8 & 8 & 18 & 18 \\
\hline & Using stairs & 51 & 51 & 46 & 46 \\
\hline & Household chores & 28 & 28 & 22 & 22 \\
\hline & Recreation & 26 & 26 & 19 & 19 \\
\hline
\end{tabular}

All patients included in the study received treatment for coronary artery disease (coronary artery bypass grafting). Moreover, all studied patients received recommendations concerning pharmacological treatment of the coronary artery disease as well as the specific concomitant condi-

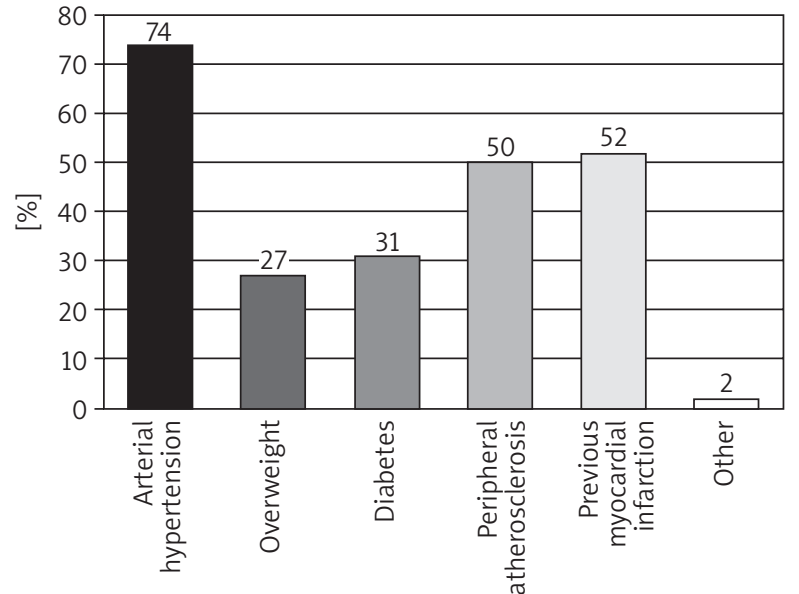

Fig. 1. Study group characteristics - concomitant diseases

tion based on the current standards. All patients were advised to take: acetylsalicylic acid, statin, a $\beta$-blocker, and an angiotensin-converting-enzyme inhibitor. All patients also received recommendations regarding their diet and were advised to limit the consumption of animal fats as well as salt (patients with arterial hypertension) and calories (overweight patients); diabetic patients were advised to follow a diabetes diet plan.

The physical activity of the study group before and after the surgery is presented in Table II.

The proportion of patients participating in physical activity after the surgery was observed to increase. After the surgery and rehabilitation, the patients experienced fewer difficulties with everyday activities than before the surgery.

The study group characteristics regarding the subjective experience of ailments associated with the disease are presented in Table III.

After the procedure and the rehabilitation process, the patients were more likely to evaluate their health status as good; however, half of the study group experienced pain in the sternal area, associated with the postoperative wound.

The study group characteristics regarding subjective mental experiences accompanying the disease are presented in Figure 2.

The study group characteristics concerning the physical and mental changes following the surgical treatment for coronary artery disease and early rehabilitation are presented in Figure 3.

The physical and mental changes after early rehabilitation were evaluated. Half of the studied patients reported improved well-being and physical condition; in turn, a third of the study group was not able to specify whether the changes were favorable, which may have stemmed from the short period that had passed from the surgical procedure. Correlation analysis demonstrated a statistically significant impact of the rehabilitation on the QoL of the studied patients $\left(p<0.01, \mathrm{~d} f=9, \chi^{2}=21.305\right)$. The influence of age on the treatment outcome was not significant $(p>0.702$, $\mathrm{d} f=12, \chi^{2}=9.006$ ); in turn, significantly better QoL improvement was observed among women in comparison to 
Tab. III. Study group characteristics - subjective ailments associated with the disease

\begin{tabular}{|c|c|c|c|c|c|}
\hline \multirow{2}{*}{\multicolumn{2}{|c|}{ Subjective ailments }} & \multicolumn{2}{|c|}{$\begin{array}{c}\text { Before } \\
\text { the procedure }\end{array}$} & \multicolumn{2}{|c|}{$\begin{array}{c}\text { After } \\
\text { the procedure }\end{array}$} \\
\hline & & $n$ & $\%$ & $n$ & $\%$ \\
\hline \multirow{3}{*}{$\begin{array}{l}\text { Health } \\
\text { status } \\
\text { perception }\end{array}$} & Good & 25 & 25 & 34 & 34 \\
\hline & Unsatisfactory & 46 & 46 & 16 & 16 \\
\hline & Difficult to define & 29 & 29 & 50 & 50 \\
\hline \multirow[t]{5}{*}{ Complaints } & Chest pain & 68 & 68 & 10 & 10 \\
\hline & Fatigability & 40 & 40 & 33 & 33 \\
\hline & Dyspnea & 50 & 50 & 12 & 12 \\
\hline & Sternal pain & 0 & 0 & 53 & 53 \\
\hline & No complaints & 14 & 14 & 23 & 23 \\
\hline \multirow{5}{*}{$\begin{array}{l}\text { Coronary } \\
\text { pain } \\
\text { occurrence }\end{array}$} & Heavy exertion & 15 & 15 & 14 & 14 \\
\hline & $\begin{array}{l}\text { Fast walking, } \\
\text { after } 200 \mathrm{~m} \text {, } \\
\text { after climbing } \\
\text { the } 2^{\text {nd }} \text { floor }\end{array}$ & 15 & 15 & 12 & 12 \\
\hline & $\begin{array}{l}\text { Everyday } \\
\text { activities, less } \\
\text { than } 200 \mathrm{~m} \text {, } \\
\text { before reaching } \\
\text { the } 2^{\text {nd }} \text { floor }\end{array}$ & 20 & 20 & 13 & 13 \\
\hline & During rest & 31 & 31 & 2 & 2 \\
\hline & No coronary pain & 19 & 19 & 59 & 59 \\
\hline
\end{tabular}

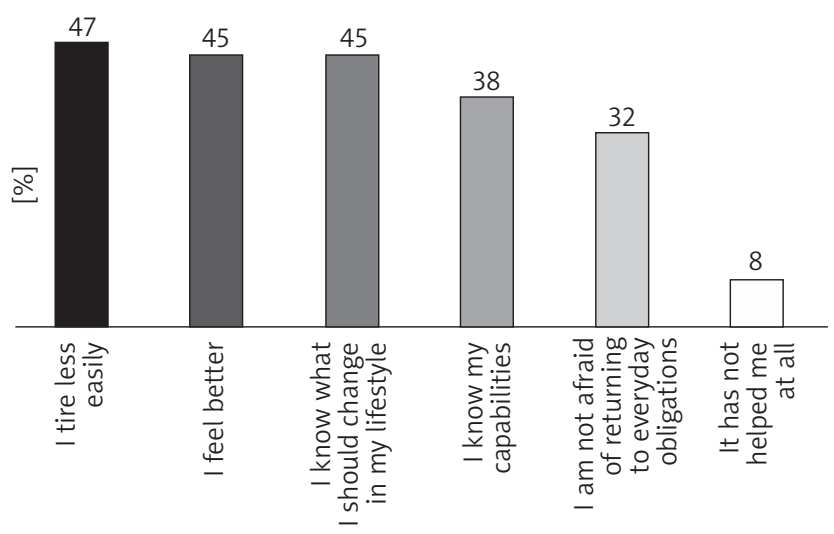

Fig. 4. Study group characteristics - activities influenced by the surgical treatment for coronary artery disease and early rehabilitation

men $\left(p<0.05, \mathrm{~d} f=3, \chi^{2}=7.759\right)$. In the study group, $64 \%$ of patients reported satisfaction from the treatment and rehabilitation, and $66 \%$ of patients stated that the early rehabilitation significantly contributed to their quicker recovery.

The study group characteristics concerning the activities influenced by rehabilitation are presented in Figure 4.

The study group characteristics concerning the quality of life after the surgical treatment for coronary artery disease and the completion of the early cardiac rehabilitation process are presented in Figure 5.

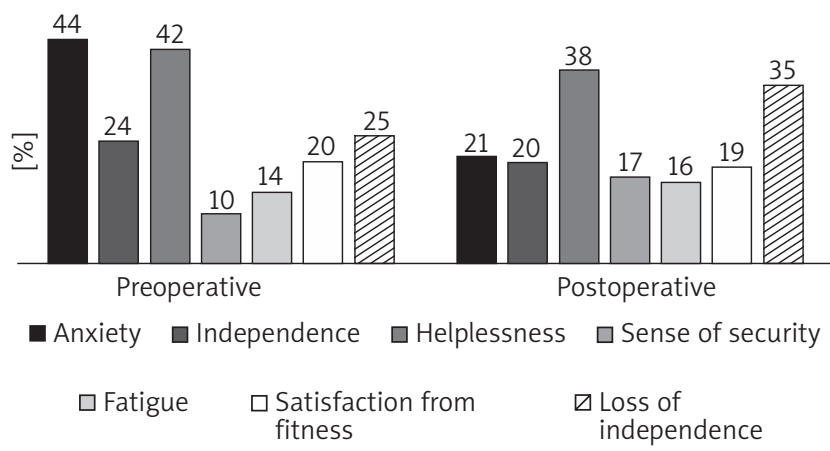

Fig. 2. Study group characteristics - subjective mental experiences accompanying the disease

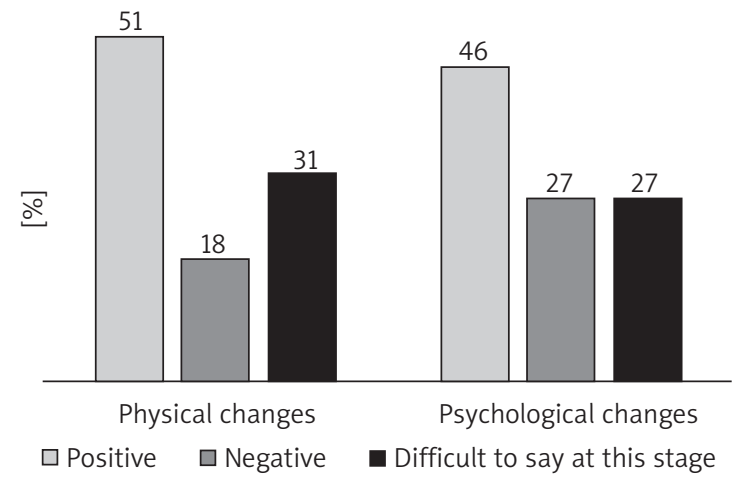

Fig. 3. Study group characteristics - physical and mental changes following the surgical treatment for coronary artery disease and early rehabilitation

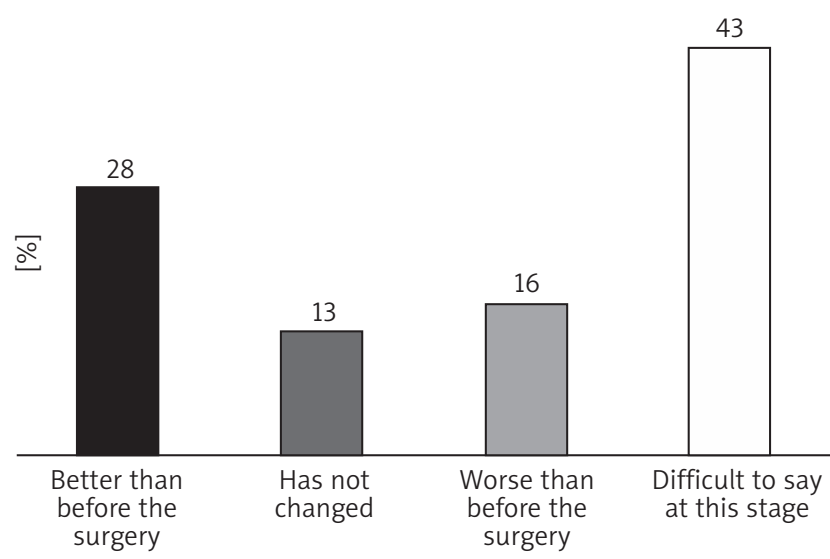

Fig. 5. Study group characteristics - quality of life of patients after surgical treatment for coronary artery disease and early rehabilitation

\section{Discussion}

Coronary artery disease is a common condition of the circulatory system; during its course, it adversely affects all aspects of functioning. Study results indicate significantly lower QoL values in patients with coronary artery disease compared to healthy individuals [12]. Factors such as age, concomitant disorders, presence of risk factors, level of knowledge, and lifestyle influence the course of the disease and its treatment as well as the quality of life of the affected patients. 
A study by Shan et al. demonstrated that the age of patients undergoing coronary artery bypass grafting is increasing [13]. Aging processes increase the risk of chronic diseases and can influence quality of life, but this relation has not been fully explained. It has been demonstrated that the presence of concomitant diseases in elderly individuals is associated with longer hospitalization and higher rates of mortality and complications. Most patients analyzed in this study were over the age of 60 . This may stem from the chronic course of ischemic heart disease and the more frequent occurrence of concomitant diseases in this age group compared to younger individuals. The studied patients were burdened with: arterial hypertension (74\%), diabetes (31\%), and overweight (27\%). Despite the factors listed above, age did not have a significant impact on the patients' quality of life. A review of the relevant literature showed that both short-term and long-term quality of life improvements are observed in elderly patients after CABG in comparison to preoperative values; QoL levels of elderly patients are better or comparable with the population of their peers, while their QoL improvement is similar to that observed among younger patients with the same condition [14-18]. Peric et al. demonstrated that, despite the presence of coronary artery disease and concomitant disorders, the QoL of patients after coronary artery bypass grafting was better among the elderly patients, which stemmed from their adaptation to the disease and its acceptance [4].

Patients after cardiac surgery procedures were more often observed to suffer from anxiety and depression. The overlap of physical and mental symptoms in these patients significantly hinders their clinical evaluation [19]. Yohannes et al. demonstrated that increased levels of depression have a significant impact on quality of life reduction in patients after surgical treatment for coronary artery disease [11]. Furthermore, Newman et al. observed impairments of attention and concentration in patients during the early postoperative period, which were associated with the patients' emotional condition [20].

In a study $12.7 \%$ of patients were diagnosed with depression, while $23.5 \%$ suffered from anxiety during the early postoperative period. Similar results were obtained in our own study, which demonstrated that, after surgical treatment and early cardiac rehabilitation, the level of anxiety among patients was reduced from $44 \%$ to $21 \%$, their sense of security increased from $25 \%$ to $35 \%$, and their satisfaction from their level of fitness increased from $10 \%$ to $17 \%$. Despite the QoL improvements in the listed areas, the results were not satisfactory. Poor mental condition of patients is attributed to many factors, including: fear of surgery, the convalescence process, social life limitations, dependence on others with regard to activities of daily life, and restriction of everyday activities [21].

Spezzaferri et al. reported that, after a year from the cardiac surgery, the levels of anxiety and depression in their subjects were significantly reduced, which likely resulted from early psychological intervention and early re- habilitation [22]. Statistical data concerning the occurrence of depression in patients after cardiac surgery vary; the reported rates range from $15 \%$ to $47 \%$. It has been demonstrated that depression in patients after coronary artery bypass grafting is an independent factor for cardiovascular event recurrence and repeated hospitalization. Therefore, particular attention should be paid to the patient's psychosocial behavior; when necessary, the patient should be provided with specialist care [23-26].

Studies by Lee et al., Pack et al., and Dayan et al. reported that early rehabilitation significantly contributed to the reduction of long-term mortality rates among CABG patients [27-29]. In turn, a study by Pourafkari et al. from 2016 demonstrated that an 8-week program of cardiac rehabilitation significantly reduced the level of depression in patients after CABG [30]. Similar results were obtained by Yohannes et al.; in their study, a 6-week rehabilitation program significantly improved QoL, including physical activity, and this improvement persisted for up to 12 months [11]. Our study also demonstrated QoL improvements. The prevalence of anxiety was reduced from $44 \%$ to $21 \%$, and the patients experienced fewer subjective ailments. Before the start of treatment and rehabilitation, chest pain, dyspnea, and fatigability were experienced by, respectively $68 \%, 50 \%$, and $40 \%$ of patients; after the procedure these rates decreased to $10 \%, 12 \%$, and $33 \%$. However, only $34 \%$ of patients believed that their health status was good, while a half of the patients were unable to define it. The subjects continued to complain of sternal pain (53\%) and leg pain (25\%), which can be explained by the short period of time that had passed since the surgery.

In short, improvements in all QoL areas were demonstrated both in the literature and our own studies. Regardless of the time passed since the completion of surgical treatment and despite the QoL improvements, the results remain unsatisfactory when we consider the psychological and social aspects of the patients' lives. Persisting high levels of anxiety and low levels of independence were factors that had a significant negative impact on QoL. This indicates a need for holistic care that would involve physicians, nurses, physiotherapists, psychologists, and the patients themselves.

This process should be continuous, widespread, available, early, and comprehensive, encompassing all aspects of the patient's life. The rehabilitation process must be continued in order to maintain the achieved effects, further improve the quality of life, and provide education to patients after surgical treatment for coronary artery disease.

\section{Conclusions}

Early cardiac rehabilitation improved the quality of life of patients after coronary artery bypass grafting as well as their awareness regarding physical activity and the required lifestyle changes.

\section{Disclosure}

Authors report no conflict of interest. 


\section{References}

1. Szyguła-Jurkiewicz B, Kowalska M, Mościński M. Jakość życia jako element oceny stanu zdrowia i efektywności leczenia chorych ze schorzeniami układu sercowo-naczyniowego. Fol Card Exc 2011; 6: 62-71.

2. Pietrasik A, Filipiak K. Co warto wiedzieć o jakości życia pacjentów z chorobą wieńcową? Fol Card Exc 2007; 2: 7-11.

3. Uchmanowicz I, Łoboz-Grudzień K. Jakość życia - definicje i narzędzia badawcze - przegląd literatury. Fam Med Prim Care Rev 2008; 10: 245-252.

4. Peric V, Jovanovic-Markovic S, Peric D, Rasic D, Novakovic, T, Dejanovic B, Borzanovic M. Quality of life in patients of different age groups before and after coronary artery by-pass surgery. Ann Thorac Cardiovasc Surg 2015; 21: 474-480.

5. Nichols M, Townsend N, Scarborough P, Rayner M. Cardiovascular disease in Europe 2014: epidemiological update. Eur Heart J 2014; 35: 2950-2959.

6. Walkowicz W, Gąsior Z, Mizia-Stec K, Dąbek J. Czynniki ryzyka zgonu lub ponownej hospitalizacji chorych z ostrym zespołem wieńcowym przed i po uprzedniej rewaskularyzacji mięśnia sercowego. Pol Merk Lek 2011; 176: 97-101.

7. Karcz M. Współczesne wskazania do rewaskularyzacji mięśnia sercowego. Terapia 2001; 19: 4-9.

8. Yalfani A, Nazem F, Safiarian R, Jargeh $M$. The effects of exercise cardiac rehabilitation on anxiety, depression and quality of life in coronary artery bypass grafting patients. Sci J Hamadan Univ Med Sci 2012; 19: 39-44.

9. Philippi A, Hoefer S, Friedrich O, Oldridge, N. Health-related quality of life predicts unplanned rehospitalization following coronary revascularization. Herz 2016; 41: 138-143.

10. Dunckley M, Ellard D, Quinn T, Barlow J. Coronary artery bypass grafting: patients' and health professionals' views of recovery after hospital discharge. Eur J Cardiovasc Nurs 2008; 7: 36-42.

11. Yohannes AM, Doherty P, Bundy C, Yalfani A. The long-term benefits of cardiac rehabilitation on depression, anxiety, physical activity and quality of life. J Clin Nurs 2010; 19: 2806-2813.

12. Smolis-Bąk E, Wójcicka M, Lewandowska M, Kazimierska B, Dabrowski R, Białoszewski D. Ocena jakości życia i poziomu depresji u pacjentów z chorobą wieńcową, leczonych inwazyjnie (PTCA, CABG) podlegających rehabilitacji szpitalnej. Postep Rehabil 2007; 3: 11-15.

13. Shan L, Saxena A, McMahon R, Newcomb A. Coronary artery bypass graft surgery in the elderly: a review of postoperative quality of life. Circulation 2013; 128: 2333-2343.

14. Graham MM, Norris CM, Galbraith PD, Knudtson ML, Ghali WA; approach Investigators. Quality of life after coronary revascularization in the elderly. Eur Heart J 2006; 27: 1690-1698.

15. Jensen $B \emptyset$, Hughes $P$, Rasmussen LS, Pedersen PU, Steinbrüchel DA. Health related quality of life following off-pump versus on-pump coronary artery bypass grafting in elderly moderate to high-risk patients: a randomized trial. Eur J Cardiothorac Surg 2006; 30: 294-299.
16. Loponen P, Luther M, Wistbacka JO, Korpilahti K, Laurikka J, Sintonen H, Huhtala H, Tarkka MR. Quality of life during 18 months after coronary artery bypass grafting. Eur J Cardiothorac Surg 2007; 32: 77-82.

17. Ghanta RK, Shekar PS, McGurk S, Rosborough DM, Aranki SF. Nonelective cardiac surgery in the elderly: is it justified? J Thorac Cardiovasc Surg 2010; 140: 103-109.

18. Krane M, Voss B, Hiebinger A, Deutsch MA, Wottke M, Hapfelmeier A, Ba diu CC, Bauernschmitt R, Lange R. Twenty years of cardiac surgery in patients aged 80 years and older: risks and benefits. Ann Thorac Surg 2011; 91: 506-513.

19. Blumenthal JA, Lett HS, Babyak MA, White W, Smith PK, Mark DB, Jones R, Mathew JP, Newman MF; NORG Investigators. Depression as a risk factor for mortality after coronary artery bypass surgery. Lancet 2003; 362: 604-609.

20. Newman MF, Kirchner JL, Phillips-Bute B, Gaver V, Grocott H, Jones RH, Mark DB, Reves JG, Blumenthal JA; Neurological Outcome Research Group and the Cardiothoracic Anesthesiology Research Endeavors Investigators. Longitudinal assessment of neurocognitive function after coronary artery bypass surgery. N Engl J Med 2001; 344: 395-402.

21. Apostolakis E. Cardiac Surgery: Perioperative Care. The Editor, Athens 2003.

22. Spezzaferri R, Modica M, Racca V, Ripamonti V, Tavanelli M, Brambilla G. Ferratini M. Psychological disorders after coronary artery by-pass surgery: a one-year prospective study. Monaldi Arch Chest Dis 2009; 72: 200-205.

23. Connerney I, Shapiro PA, McLaughlin JS, Bagiella E, Sloan RP. Relation between depression after coronary artery bypass surgery and 12-month outcome: a prospective study. Lancet 2001; 358: 1766-1771.

24. Tully PJ, Pedersen SS, Winefield HR, Baker RA, Turnbull DA, Denollet J. Cardiac morbidity risk and depression and anxiety: a disorder, symptom and trait analysis among cardiac surgery patients. Psychol Health Med 2011; 16: 333-345.

25. Tully PJ, Baker RA. Depression, anxiety, and cardiac morbidity outcomes after coronary artery bypass surgery: a contemporary and practical review. J Geriatr Cardiol 2012; 9: 197-208.

26. Tully PJ, Baker RA, Turnbull D, Winefield $H$. The role of depression and anxiety symptoms in hospital readmissions after cardiac surgery. J Behav Med 2008; 31: 281-290.

27. Lee JY, Park EK, Ahn JM, Park H, Cheon SS, Kim MS, Choi HI. Impact of partici pation in cardiac rehabilitation on long-term survival after coronary artery bypass graft surgery. Circulation 2014; 130: A18567.

28. Pack QR, Goel K, Lahr BD, Greason KL, Squires RW, Lopez-Jimenez F, Thomas RJ. Participation in cardiac rehabilitation and survival after coronary artery bypass graft surgery: a community-based study. Circulation 2013; 128: 590-597.

29. Dayan V, Ricca R. Cardiac rehabilitation after coronary artery bypass surgery. Arch Cardiol Mexico 2013, 84: 286-292.

30. Pourafkari L, Ghaffari S, Tajlil A, Shahamfar J, Hedayati S, Nader ND. The impact of cardiac rehabilitation program on anxiety and depression levels after coronary artery bypass graft surgery. Cor et Vasa 2016; 58: 384-390. 


\section{QUESTIONNAIRE}

Dear Sir or Madam, we invite you to fill out the following questionnaire concerning your quality of life after surgical treatment for coronary artery disease (bypass grafting). Your participation is completely anonymous and voluntary.

Sex: Woman [ ] Man [] Age:

Place of residence: Urban [ ] Rural [ ]

Education: Primary [] Secondary [ ] Vocational [ ] Higher [ ]

Marital status:

What is/was your occupation? Physical work [ ] Intellectual work [ ]

Was your coronary artery bypass grafting procedure:
a) Urgent [ ]
b) Semi-elective [ ]
c) Elective [ ]

Would you describe your health status as good?

a) Yes [ ] b) No [ ] c) Difficult to say [ ]

Are/were you a smoker?
a) No, never []
b) Yes, but I quit [ ]
c) Yes, I smoke [ ]

Please mark the conditions that affect you (more than one can be selected):
a) Arterial hypertension [ ]
b) Overweight [ ]
c) Diabetes [ ]
d) Atherosclerosis [ ]

Which ailments did you find most troublesome in you daily functioning? (more than one can be selected)
a) Chest pain [ ]
b) Fatigability [ ]
c) Dyspnea [ ]
d) No ailments [
e) Leg pain [ ]
f) Sternal pain [ ]
g) Myocardial infarction [ ]
h) Other [ ]

Which aspects of your life were most affected by the disease? (more than one can be selected)
a) Physical fitness [ ]
c) Hobbies and interests [ ]
e) Professional work [ ]
b) Mental well-being [ ]
d) Household chores [ ]
f) Relationships with family and friends [ ]

g) Other [ ]

Which aspects of your life improved the most after the surgery and rehabilitation?
a) Physical [ ]
b) Mental [ ]
c) Difficult to specify, it's too early after the procedure [ ]
d) None [ ]

When do/did you experience coronary pain?

a) During very long and heavy physical exertion [ ]

b) When walking quickly or climbing stairs, after $200 \mathrm{~m}$, after reaching the $2^{\text {nd }}$ floor [ ]

c) During everyday activities, after walking less than $200 \mathrm{~m}$, before reaching the $2^{\text {nd }}$ floor [ ]

d) During minimal exertion or rest [ ]

e) I did not experience coronary pain [ ]

To what extent are/were your daily activities limited?

a) I did not experience any limitations of my daily activities [ ]

b) My everyday activities were slightly limited [ ]

c) I experienced significant limitations of my everyday activities [ ]

d) My everyday activities were very limited [ ]

Which of these activities did you find difficult? (more than one can be selected)
a) Dressing, using
the bathroom []
d) Using stairs [ ]
b) Walking slowly [ ]
c) Walking quickly [ ]
g) Sports [ ]
e) Household chores [ ] f) Recreation activities [ ]

Did you have to rely on the help of others with everyday activities? a) Yes [ ] b) Only with some activites [ ] c) No [ ]

\section{What were your primary free-time activities?}

a) Watching TV, reading books, sleeping [ ]

b) Walking, movement, recreation [ ]

c) Household chores, gardening [ ]

What were your primary physical activities?
a) Household chores, gardening [ ]
b) Professional work [ ]
c) Recreation (swimming, cycling, walking) [ ]
d) No activity [ ]

\section{How often did you engage in physical activity?}
a) I am not physically active [ ]
c) Twice per month [ ]
b) Once per month [ ]
e) Several times per week [ ]
d) Once per week [ ]
f) Every day [ ]

Which of these experiences did you encounter? (more than one can be selected)
a) Anxiety [ ]
$\begin{array}{ll}\text { b) Helplessness [ ] } & \text { c) Fatigue [ ] }\end{array}$
d) Loss of independence [ ] e) Sense of independence [ ]
f) Sense of security [ ]
g) Satisfaction from your level of fitness [ ]

Did you experience health-related anxiety?

a) Yes, often [ ] b) Yes, sometimes [ ] c) Yes, but rarely [ ] d) No [ ]

What is your role in the treatment and rehabilitation process?

a) I have no influence over the improvement of my health. [ ]

b) My influence over the improvement of my health is very limited. [ ]

c) My engagement has a significant influence over the improvement of my health. [ ]

Your quality of life after the treatment and rehabilitation:

a) ... is better than before the surgery [ ]

b) ... has not changed [ ]

c) ... is worse than before the surgery [ ]

d) ... is difficult to evaluate so early after the surgery [ ]

In what ways was your treatment and rehabilitation process helpful? (more than one can be selected)
a) I tire less easily [ ]
b) I feel better [ ]
c) I know what I should change in my lifestyle [ ]
d) I know my capabilities [ ]
e) I am not afraid of returning to everyday obligations [ ]
f) It has not helped me at all [ ]

Are you going to rely on the help of others after leaving the hospital?

a) Yes, I cannot imagine functioning on my own [ ]

b) Yes, but only with some activities [ ]

c) No, I will not require help [ ]

Are you considering going back to professional work?

a) Yes [ ]

b) No [ ]

c) I don't know yet [ ]

d) No, I'm on pension/retired/unemployed [ ] 